\title{
Determination of neosaxitoxin in biota of Lake Baikal: preliminary observations
}

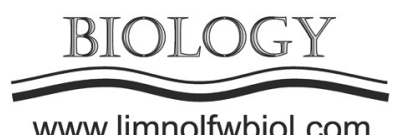

www.limnolfwbiol.com

\author{
Kuzmin A.V. ${ }^{1 *}$, Belykh O.I. ${ }^{1}$, Tikhonova I.V. ${ }^{1}$, Grachev M.A. ${ }^{1}$, Fedorova G.A. ${ }^{1,2}$ \\ ${ }^{1}$ Limnological Institute, Siberian Branch of the Russian Academy of Sciences, Ulan-Batorskaya Str., 3, Irkutsk, 664033, Russia \\ ${ }^{2}$ Russian State University of Justice, 23-A, Ivana Franko, Irkutsk, 664033, Russia
}

\begin{abstract}
Benthic biofilms, macrocolonies and net plankton samples collected in summer from well warmed-up bays and shallow waters of Lake Baikal during the mass development of cyanobacteria were studied. The contents of saxitoxin and neosaxitoxin were determined by means of liquid chromatography mass spectrometry in the form of 2,4-dinitrophenylhydrazine derivatives. The production of paralytic shellfish toxins and the saxitoxin/neosaxitoxin ratio depend on the species of cyanobacteria were also determined. Nowadays, the planktonic and benthic cyanobacteria of Lake Baikal can be considered as a natural source of neosaxitoxin only for research purposes. However, with obtaining cultured strains among the studied species, they can be used soon as producers.
\end{abstract}

Keywords: Neosaxitoxin, Lake Baikal, high performance liquid chromatography, mass spectrometry, derivatization, 2,4-dinitrophenylhydrazine

\section{Introduction}

Neosaxitoxin (NEO) is a compound of the group consisting of $\sim 60$ structurally related natural chemicals called paralytic shellfish toxins (PSTs). Some representatives of dinophytes, including species of the genus Alexandrium (A. andersoni, A. catenella, A. excavatum, A. fundyense, A. minutum, A. ostenfeldii, A. tamarense, and A. tamiyavanichi), as well as species Gymnodinium catenatum and Pyrodinium bahamense, are saxitoxin producers in marine resources (Llewellyn, 2006). At the same time, cyanobacteria of genera Anabaena, Cylindrospermopsis, Aphanizomenon, Planktothrix, Lyngbya, etc. are the PST producers in freshwater bodies (Wiese et al., 2010). In addition to the direct production by cyanobacteria, NEO, and some other PST variants, can be a product of enzymatic oxidation of gonyautoxins 1 and 4 (GTX1/4) (Sugawara et al., 1997).

Filter feeding shellfish that consume dinophytes is capable of bioaccumulating PSTs in high concentrations, which is hazardous to humans who use them as a food (Negri et al., 1995). In freshwater bodies, PSTs are mainly orally transmitted to humans and animals, for example, via drinking water.

Neosaxitoxin and its analogues target integral membrane protein (voltage-gated sodium channel (VGSCs or Nav channel) involved in the transmission of electrical signals in cell and the distribution of the action potential, basic physiological processes of the nervous system (Cestèle and Catterall, 2000; Yu and Catterall,
2003). The toxic effect of PSTs on living organisms arise from sodium channel blocking of electrically excitable membranes in nerve and muscle cells by the guanidine fragment in the structure of the toxin. The toxic effect of PSTs on living organisms occurs when the sodium channel of electrically excited membranes in nerve and muscle cells is blocked by a fragment of guanidine in the structure of the toxin. This leads to a decreased production of nerve impulses in tissues and organs. An acute toxicity arises even at minimal doses of saxitoxins (STXs) and can result in rapid death from paralysis of respiratory muscles, whose membranes are rich in sodium channels.

Blocking of sodium channels by saxitoxins in nerve cells is similar to tetrodotoxin (TTX) action mechanism. Such a unique feature of STXs made it possible to study neosaxitoxin as an analgesic for local anaesthesia in clinical practice (Rodriguez-Navarro et al., 2007; 2011) and veterinary medicine (Riquelme et al., 2018; Varela et al., 2019).

After a single injection, neosaxitoxin (individually or combined) has provided prolonged analgesia from one to three days. NEO is more effective and less toxic than STX (Manríquez et al., 2015; Rathmell et al., 2015), and currently it is in clinical trial phase no. 1 (Rodriguez-Navarro et al., 2007; 2011).

Prolonged analgesic effect of NEO at extremely low therapeutic doses (50-100 $\mu \mathrm{g} /$ day) is due to its high affinity and specificity for targets of the peripheral nervous system. Owing to low concentrations together

*Corresponding author.

E-mail address: kuzmin@lin.irk.ru (A.V. Kuzmin) 
with the inability to overcome the blood-brain barrier and affect the central nervous system, there are no dose-depending side effects as well as physiological and psychological dependences, in contrast to narcotic analgesics (Rodriguez-Navarro et al., 2011; Riquelme et al., 2018; Varela et al., 2019).

We previously reported the presence of saxitoxin and its analogues' producers in Lake Baikal and other water bodies of the Irkutsk Region (Belykh et al., 2020). All investigated samples, except for plankton samples collected near the Turka settlement (August 2010), were analysed only by enzyme-linked immunosorbent assay (ELISA), while PST variants were identified by the MALDI-TOF/TOF method.

The plankton samples from Barguzin Bay contained STX and NEO; those from Kurkut Bay - STX and decarbamoylated derivatives of gonyautoxins, dcGTX1/4 and dcGTX2/3 (Lake Baikal, August 2010) (Belykh at el., 2015). In benthic biofilms (settlements of Listvyanka and Bolshiye Koty, September 2015), eight variants with different toxicity (STX, NEO, dcGTX1/4, dcGTX2/3, GTX5, dcSTX, dcNEO, and doGTX2/4) were detected (Belykh et al., 2016).

A preliminary assessment of the total STX content in water, planktonic and benthic samples was carried out by ELISA method using the Abraxis Saxitoxin ELISA kit test system (Abraxis LLC, United States) with a determination limit of $0.015 \mu \mathrm{g} / \mathrm{L}$. ELISA has a high sensitivity, nevertheless it cannot assess the concentration of individual toxins. Moreover, the specificity of the test system depends on the STX nature and varies from $100 \%$ for saxitoxin to $1.3 \%$ for neosaxitoxin as well as $<0.2 \%$ for gonyatoxin 1 and 4 .

High performance liquid chromatography-mass spectrometry (HPLC-MS) combines the ability of high sensitive mass spectrometric detection of individual saxitoxins and capable to selective separation of studied mixtures thus can be considered as one of the powerful and universal methods for determination of target compounds.

Therefore, we aimed to study phytoplankton and phytobenthos of Lake Baikal as a natural source of pharmacologically significant substance - neosaxitoxin, using HPLC-MS.

\section{Materials and methods}

The following equipment and materials were used in present study:

An ultrasonic homogenizer UP100H (Hielscher Ultrasonic, Germany); MiniSpin microcentrifuge (Eppendorf, Germany); Freeze dryer CoolSafe (Scanlaf, Denmark); Concentrator Plus vacuum centrifuge (Eppendorf, Germany); Analytical + analytical balances (OHAUS Europe, Switzerland); Sonorex ultrasonic bath (Bandelin, Germany); household refrigerator with a freezer (Stinol, Russia);

Agilent 6210 time-of-flight mass spectrometer with electrospray ionization (ESI-MS-TOF) coupled to an Agilent 1200 liquid chromatography system (HPLCDAD) with a Zorbax 300SB-C18 (5 $\mu \mathrm{m} ; 2,1 \times 150 \mathrm{~mm})$ column. Eluent A was 0,1\% heptafluorobutyric acid (HFBA) in water, and eluent B was $0,1 \%$ HFBA solution in acetonitrile. The column temperature was $35^{\circ} \mathrm{C}$. The column was preconditioned with $100 \%$ eluent B for 15 $\min$ at $0,2 \mathrm{ml} / \mathrm{min}$, then $10 \%$ eluent $\mathrm{B}$ for $15 \mathrm{~min}$ at $0,2 \mathrm{ml} / \mathrm{min}$. Gradient elution ( $10 \%$ eluent $\mathrm{B}$ to $100 \%$ eluent B) was performed at a flow rate of $0,15 \mathrm{ml} /$ min for $20 \mathrm{~min}$. The detection mode was electrospray ionization with positive ion registration $(\mathrm{ESI}+)$. The range of detection was 100 to $600 \mathrm{Da}$, and the ion source temperature was set at $250^{\circ} \mathrm{C}$, gas flow was 3,5 $\mathrm{L} / \mathrm{min}$, nebulizer was 45 psi.

Distilled water, acetic acid (analytical grade, Reakhim, Russia), chloroform (analytical grade, Kriokhrom, Russia), acetonitrile (HPLC grade, AppliChem, Germany); trifluoroacetic acid (analytical grade, Panreac, Germany); heptafluorobutyric acid (99.5\%, FluoroChem, UK); 2,4-dinitrophenylhydrazine (double recrystallized from ethanol, Reakhim, Russia), standard saxitoxin solution with a concentration of 63.3 $\mu \mathrm{mol} / \mathrm{L}$ (National Research Council, Canada).

\section{Results and discussion}

Plankton samples were taken in mid-July-August, during the mass development of cyanobacteria, from bays and shallow waters that warm up well in summer. The sampling method was chosen depending on the habitat and species of cyanobacteria. Plankton was sampled using the Apstein net $(20 \mu \mathrm{m})$ from a depth of 0-5 m. Nostoc pruniforme existing in nature as separate large spherical colonies were manually collected from the soil surface of edge water zone. Gloeotrichia echinulate, a species forming freely floating spherical colonies (up to $2-5 \mathrm{~mm}$ in diameter) and visible in water, were collected together with the surface water. The samples were frozen and delivered to the laboratory. In total, eight samples, whose sampling sites are shown in the Table, were studied.

After thawing at room temperature, large colonies were shredded into small parts (less than 5 $\mathrm{mm}$ ); the small ones were filtered through the fabric. Unstructured samples were mixed well (more than 5 min), placed to the Petri dishes, and large inclusions (particles of sand, wood and etc.) were removed. The obtained samples were further lyophilized. After that, different parts of the dried sample from the dish (centre and several points throughout the area) were transferred to a mortar and ground for five minutes. Ground samples were transferred to test tubes and stored at $-20^{\circ} \mathrm{C}$ until analysis.

The extraction of toxins and its derivatization with 2,4-dinitrophenylhydrazine were carried out following the procedure, which was previously proposed by us for saxitoxin (Grachev et al., 2018; Zubkov et al., 2018). The table shows the results of the study.

The present study has revealed that Nostoc pruniforme and Gloeotrichia echinulata are capable of simultaneous production of STX and NEO. The samples of benthos, where the species Tolypothrix distorta is a likely producer of PSTs, have indicated only STX or 
Table 1. Results of saxitoxin and neosaxitoxin content in biota samples from the coastal zones of Lake Baikal

\begin{tabular}{|c|c|c|c|c|c|}
\hline Entry & Sampling site & Sample type & $\begin{array}{l}\text { Probable PST pro- } \\
\text { ducer/Dominant } \\
\text { species }\end{array}$ & $\underset{\text { mass }}{S T X, \mu g / k g \text { of dry }}$ & $\begin{array}{l}\text { NEO, } \mu \mathrm{g} / \mathrm{kg} \text { of } \\
\text { dry mass }\end{array}$ \\
\hline 1 & Listvennichny Bay & Benthic fouling & Tolypothrix distorta & $900 \pm 150$ & nd \\
\hline 2 & $\begin{array}{c}\text { Bolshoye Goloustnoye } \\
\text { settlement }\end{array}$ & Benthic fouling & Tolypothrix distorta & nd & nd \\
\hline 3 & Bolshiye Koty settlement & Benthic fouling & Calothrix sp. & nd & nd \\
\hline 4 & Aya Bay (Lake Baikal) & Benthic fouling & $\begin{array}{l}\text { Chamaesiphon con- } \\
\text { fervicolus }\end{array}$ & $250 \pm 100$ & nd \\
\hline 5 & Mukhor Bay & Macrocolonies & Nostoc pruniforme & $3800 \pm 600$ & $1300 \pm 200$ \\
\hline 6 & $\begin{array}{l}\text { Mukhor Bay (the Kuchel- } \\
\text { ga River, estuary) }\end{array}$ & Net plankton sample & $\begin{array}{l}\text { Gloeotrichia echinu- } \\
\text { lata }\end{array}$ & $430 \pm 100$ & $2200 \pm 300$ \\
\hline 7 & $\begin{array}{l}\text { Mukhor Bay (the Kuchel- } \\
\text { ga River, } 1,5 \mathrm{~km} \text { to the } \\
\text { north of the estuary) }\end{array}$ & Net plankton sample & $\begin{array}{l}\text { Gloeotrichia echinu- } \\
\text { lata }\end{array}$ & $400 \pm 100$ & $2300 \pm 400$ \\
\hline 8 & The Ushkany Islands & Macrocolonies & Nostoc commune & nd & nd \\
\hline
\end{tabular}

no toxins, as in the sample consisting mainly of the Calothrix sp. filaments.

The ratio of toxin variants in samples depends on the species of dominant cyanobacteria. For example, plankton samples, in which Gloeotrichia echinulata (entry 6 and 7) prevailed, contain the greatest amount of NEO (Table). The Nostoc pruniforme macrocolonies contain the maximum amount of STX (entry 5).

The concentration of NEO in the sample with dominant Gloeotrichia echinulata from Lake Baikal (Table) is comparable with other members of the order Nostocales, e.g. Aphanizomenon DC-1 from Dianchi Lake (China), $2279 \mu \mathrm{g} / \mathrm{kg}$ (Liu, 2006), and more than nine times higher than in Aphanizomenon flos-aquae isolated from the water of Montargil Lake in Portugal (Pereira, 2000).

It is worth to be mentioned that the required single dose of NEO as a local anaesthetic for an adult is 50-100 $\mu$ g (Rodriguez-Navarro et al., 2007; 2011). The low concentration of NEO in cyanobacteria from Lake Baikal and a short period of their mass development allows us to conclude that it is inappropriate to consider natural samples from the lake as a source of NEO for commercial uses.

At present time, an organic synthesis approach can be the main source of NEO for pharmaceutical purposes. Despite the method is extremely laborious, the target yield for $(+) S T X$, as an example, is up to $70 \%$ yield (Fleming at al., 2006).

On the other hand, the colonies of Nostoc pruniforme and Gloeotrichia echinulate are convenient for collection; the concentrations of toxins in them are sufficient for scientific purposes. Therefore, we assume that with the capabilities of modern analytical equipment for extracting individual toxins one can consider Lake Baikal as a natural source of toxins for research aims. Furthermore, upon obtaining pure cultures of cyanobacteria and choosing the optimal cultivation conditions, their use in medicine is also possible.

\section{Conclusions}

Present study revealed the production of neosaxitoxin by cyanobacteria in various habitats of Lake Baikal. The Nostoc pruniforme and Gloeotrichia echinulata cyanobacteria are capable of simultaneous production of NEO and STX. Samples of benthos, where the species Tolypothrix distorta is a probable producer of PSTs, contained only STX. The production and the ratio of toxin variants in phytoplankton depend on species of cyanobacteria. Thus, plankton samples with prevailing Gloeotrichia echinulata showed the greatest amount of neosaxitoxin. The Nostoc pruniforme macrocolonies contained the maximum amount of saxitoxin. Nevertheless, Baikal cyanobacteria produce a small amount of neosaxitoxin; therefore, it is possible to consider Lake Baikal as a natural source of neosaxiton only for research purposes.

\section{Acknowledgements.}

Analytical equipment was provided by the Shared Research Facilities for Physical and Chemical Ultramicroanalysis LIN SB RAS. This work was carried out within the State Task (Project No. 0345-20180005, Project No. 0345-2018-0003) and supported by the Russian Foundation for Basic Research and the Government of the Irkutsk Region (RFBR; Grant No. 17-44-388091)

\section{References}

Belykh O.I., Tikhonova I.V., Kuzmin A.V. et al. 2020. Toxin-producing cyanobacteria in Lake Baikal and water bodies of the Baikal region (review). Teoreticheskaya $i$ prikladnaya ecologiya [Theoretical and Applied Ecology] 1: 21-27. (in Russian)

Belykh O.I., Glagkikh A.S., Tikhonova I.V. et al. 2015. Identification of cyanobacterial producers of shellfish paralytic toxins in Lake Baikal and reservoirs of the Angara river. Microbiology (Mikrobiologiya) 84: 98-99. DOI: 10.1134/S0026261715010038 
Belykh O.I., Tikhonova I.V., Kuzmin A.V. et al. 2016. First detection of benthic cyanobacteria in Lake Baikal producing paralytic shellfish toxins. Toxicon 121: 36-40. DOI: 10.1016/j.toxicon.2016.08.015

Cestèle S., Catterall W.A. 2000. Molecular mechanisms of neurotoxin action on voltage-gated sodium channels. Biochimie 82: 883-892. DOI: 10.1016/s0300-9084(00)01174-3

Grachev M., Zubkov I., Tikhonova I. et al. 2018. Extensive contamination of water with saxitoxin near the dam of the Irkutsk hydropower station reservoir (East Siberia, Russia). Toxins 10: 1-12. DOI: 10.3390/toxins10100402.

Fleming J.J., Du Bois J. 2006. A Synthesis of (+ )-saxitoxin. Journal of the American Chemical Society 128: 3926-3927. DOI: $10.1021 /$ ja0608545

Liu Y.M., Chen W., Li D.H. et al. 2006. Analysis of paralytic shellfish toxins in Aphanizomenon DC-1 from Lake Dianchi, China. Environmental Toxicology 21: 289-295. DOI: 10.1002/tox.20182

Llewellyn L.E. 2006. Saxitoxin, a toxic marine natural product that targets a multitude of receptors. Natural Product Reports 23: 200-222.

Manríquez V., Castro Caperan D., Guzmán R. et al. 2015. First evidence of neosaxitoxin as a long-acting pain blocker in bladder pain syndrome. International Urogynecology Journal 26: 853-858. DOI: 10.1007/s00192-014-2608-2

Negri A.P., Jones G.J. 1995. Bioaccumulation of paralytic shellfish poisoning (PSP) toxins from the cyanobacterium Anabaena circinalis by the freshwater mussel Alathyria condola. Toxicon 33: 667-678. DOI: 10.1016/0041-0101(94)00180-g

Pereira P., Onodera H., Andrinolo D. et al. 2000. Paralytic shellfish toxins in the freshwater cyanobacterium Aphanizomenon flos-aquae, isolated from Montargil reservoir, Portugal. Toxicon 38: 1689-1702. DOI: 10.1016/ s0041-0101(00)00100-8

Rathmell G.P., Strichartz G., Wanderer G. 2015. Neosaxitoxin versus traditional local anesthetics: mechanism of action and sites of notable effect. Anesthesiology 123. DOI: 10.1097/01.anes.0000470956.02665.a6

Riquelme G., Sepúlveda J.M., Al Ghumgham Z. et al. 2018. Neosaxitoxin, a Paralytic Shellfish Poison toxin, effectively manages bucked shins pain, as a local long-acting pain blocker in an equine model. Toxicon 141: 15-17. DOI: 10.1016/j.toxicon.2017.11.004

Rodriguez-Navarro A.J., Lagos N., Lagos M. et al. 2007. Neosaxitoxin as a local anesthetic: preliminary observations from a first human trial. Anesthesiology 106: 339-345.

Rodriguez-Navarro A.J., Berde Ch.B., Wiedmaier G. et al. 2011. Comparison of neosaxitoxin versus bupivacaine via port infiltration for postoperative analgesia following laparoscopic cholecystectomy a randomized, double-blind trial. Regional Anesthesia and Pain Medicine 36: 103-109.

Sugawara A., Imamura T., Aso S. et al. 1997. Change of paralytic shellfish poison by the marine bacteria living in the intestine of the Japanese surf clam, Pseudocardium sybillae, and the brown sole, Pleuronectes herensteini. Scientific Reports of Hokkaido Fisheries Experimental Station 50: 35-42.

Varela X., Del Campo M., Piron R. et al. 2019. Effect of neosaxitoxin on epidural anesthesia in cats: a promising alternative to conventional anesthetics. International Physiology Journal 2: 4-10.

Wiese M., D'Agostino P.M., Mihali T.K. et al. 2010. Neurotoxic alkaloids: saxitoxin and its analogs. Marine Drugs 16: 2185-2211. DOI: $10.3390 / \mathrm{md} 8072185$

Yu F.H., Catterall W.A. 2003. Overview of the voltagegated sodium channel family. Genome Biology 4. DOI: 10.1186/gb-2003-4-3-207

Zubkov I.N., Kuzmin A.V., Tikhonova I.V. et al. 2018. Determination of saxitoxin by HPLC-MS with the 2,4-dinitrophenylhydrazine precolumn derivatization. Izvestiya Vuzov. Prikladnaya Khimiya i Bitekhnologiya [Bulletin of Universities. Applied Chemistry and Biotechnology] 8: 25-32. (in Russian) 